\title{
People of Chinese Heritage in Australian National Memory
}

\author{
Tiping Su * \\ Centre for Australian Studies \\ Xi'an International Studies University \\ Xi'an, China \\ sue6415@126.com
}

\begin{abstract}
National biography is a kind of national memory. The Australian Dictionary of Biography (ADB) is an Australian national memory and has been the great repository of the Australian identity. In order to measure the position of people of Chinese heritage in the Australian national memory, this paper surveys the people of Chinese heritage in the $A D B$ and figures out its proportion. Compared with the proportion of Chinese people in Australia historically and presently, this ethnic group, as a very important part of Australians, is both omitted and under-represented in the $A D B$, totally or individually. As a national memory, this kind of negligence will affect construction of Australian identity and the image of a "real” Australia.
\end{abstract}

Keywords-Chinese heritage, ADB, national biography, national memory

\section{INTRODUCTION}

National biography is a kind of national memory, especially in the English countries. The main English countries all have national biographies, such as the Oxford Dictionary of National Dictionary (Oxford DNB), which succeeded the Dictionary of National Biography (DNB) first published from 1885 in UK, the American National Biography (ANB), a successor of the Dictionary of American Biography first published between 1926 and 1937, the Dictionary of Canadian Biography (DCB) and a French version Dictionnaire biographique du Canada from Canada, the Dictionary of New Zealand Biography (DNZB) from New Zealand, and the Australian Dictionary of Biography (ADB) as well. Although not all these dictionaries are sponsored by the governments, and some of them do get assistance from the government, e.g. DNZB, but they all bear the function of national memory and claim "a dictionary of biographical entries for individuals who have contributed to the history" [1], just as Oxford DNB notes it "is the national record of men and women who have shaped British history and culture, worldwide, from the Romans to the 21st century" [2]. The $A D B$ is no exception, and it states that it records "the lives of over 12,000 significant and representative persons in Australian history. The subjects come from all walks of life - from prime ministers, governors-general and premiers, generals and bishops, artists, actors and authors, engineers and schoolteachers, to prostitutes, thieves and murderers - providing a cross-section of Australian society" [3]. As emigrant nations, Australia for instance, are all the people of different heritages equally represented? This paper

This paper is sponsored by a grant from the Key Program of Education Department of Shaanxi Provincial Government, China "Evolution ofEthnic Identity and National Identity in Australian Aboriginal Literature” (Program No. 17JZ061) will take the people of Chinese heritage as an example to analyze their position in the $A D B$ and in the Australian national memory.

\section{Proportion of Chinese People in CuRrent AND HistORICAL AUSTRALIA}

According to the Census of Population and Housing (2011) by Australian Bureau of Statistics (ABS), there were 5.3 million migrants in Australia, which means 26 per cent of the Australian residents were born overseas. The United Kingdom (UK) is the largest contributor to Australia's migrant population, which contributes 1.1 million UK-born migrants to Australia. New Zealand is the second largest one-close to half a million people (483,000 people), and next to New Zealand is China-319,000 people. Compared with Census 2001, the China-born migrants have exceeded those born in Italy and Vietnam and have been the third largest migrant group. And the next years see the trend continues, which can be testified by the ABS Migration Summary of 2016. What's more, Chinese from Hong Hong, Macao and Taiwan are excluded in this census. The statistics also show that over 135,000 Chinese international students registered in 2014, which contributed 27.3 per cent of all international students in Australia and is much higher than India, the second, contributing only 10.8 per cent. There are more and more Chinese students come to study in Australia and a rip-snorting 46,370 new Chinese students have already commenced courses by the first season of 2016. It is estimated that there are near one million Chinese living in Australia now. Somebody even predicted "there would be an estimated four to five million people of Chinese heritage living in Australia within the next 20 years" [4]. From the above data, we can come to a conclusion with no big efforts that people of Chinese heritage will be a very important part of Australian population.

Historically, the Chinese people are also holding a certain component in Australian population. It was estimated that there were more than 200,000 Chinese people in 1870s, but which could not be testified with written documents. According to the Australian official data, there were 24,732 Chinese people living in Victoria and 13,000 in New South Wales in 1861. The Chinese official data shows that approximately 55,000 people left for Australia during 1851 to 1875 . In fact, scholars believe that more people escaped register by the authorities. The following table shows the population change of Chinese people in Australian official documents from 1861 to 1947. (See Table 
I) [5] In a word, historically or currently, the Chinese people are a force to be reckoned with in number.

TABLE I. CHINESE LIVING IN AUSTRALIA 1861-1947

\begin{tabular}{|l|l|l|l|}
\hline Year & Population of Chinese & Population Of Australia & $\%$ \\
\hline 1861 & 38,348 & & 3.3 \\
\hline 1871 & 28,460 & & 1.7 \\
\hline 1881 & 38,702 & $2,250,194$ & 1.7 \\
\hline 1891 & 35,821 & $3,174,392$ & 1.1 \\
\hline 1901 & 29,527 & $3,773,801$ & 0.78 \\
\hline 1911 & 22,753 & $4,455,005$ & 0.51 \\
\hline 1921 & 15,224 & $5,435,734$ & 0.28 \\
\hline 1933 & 7,792 & $6,629,839$ & 0.12 \\
\hline 1947 & 4,858 & $7,579,358$ & 0.06 \\
\hline
\end{tabular}

III. People of Chinese Heritage in Contrast with OTHER ETHNIC GROUPS IN THE ADB

As a national memory, the $A D B$ is "the largest and most successful cooperative research enterprise in the humanities and social sciences in Australia”. This is an evaluation on the $A D B$ given by Tom Griffiths, a famous historian and the chairman of the editorial board of the $A D B$, and he stressed this was a "national mission". [6] The Chancellor of the ANU, Professor the Hon. Gareth Evans AC QC claimed, "The Australian Dictionary of Biography captures the life and times and culture of this country in an absolutely distinctive and irreplaceable way." [6] As a national mission, it should bear the function of representing the whole nation or reflecting the whole picture of the country. On the home page of the $A D B$ online, it also states "the Australian Dictionary of Biography is Australia's pre-eminent dictionary of national biography. In it you will find concise, informative and fascinating descriptions of the lives of significant and representative persons in Australian history”.

The $A D B$, begun by Fitzhardinge in 1954 and the first volume launched in 1966, has recorded 12,955 persons in the history of Australia so far. Among these people, 4,834 subjects are of English heritage, 1,622 of Scottish heritage and 159 of Welsh heritage in addition to 1,511 of Irish heritage. Of the people of Irish heritage, the $A D B$ does not distinguish the people from the North Ireland and those from the Republic of Ireland. Except the Irish descendants, the people of English, Scottish and Welsh heritages add up to 6,615. If the people from the North Ireland are taken into account, there are more UK-descendants than the present number 6,615, which occupies at least 51 percent of the subjects of the $A D B$. In contrast, other ethnic groups have a much low percentage. Take the people from the top 10 countries of birth shown in Migration Summary 2016 as an example, 294 people of New Zealander heritage are included, and others include 32 Chinese, 12 Indians, 88 Italians, 20 South Africans, 2 Malayan (Malaysians) and 320 Germans, but no Philippines and Vietnamese. People of different cultural heritages recorded in the $A D B$ are out of proportion to the number of their present resident population. Compared with the Europeans, the Asians are much less in proportion. (See Table II).

TABLE II. PEOPLE OF THE TOP 10 COUNT RIES OF BIRTH RECORDED IN THE ADB

\begin{tabular}{|l|l|l|l|l|l|l|l|l|l|l|}
\hline CTRY & UK & NZ & CHN & IND & PHI & VN & ITA & SA & MY & GER \\
\hline NUN & 6615 & 294 & 32 & 12 & 0 & 0 & 88 & 29 & 2 & 320 \\
\hline
\end{tabular}

\begin{tabular}{l|l|l|l|l|l|l|l|l|l|l|} 
NUN & 6615 & 294 & 32 & 12 & 0 & 0 & 88 & 29 & 2 & 320 \\
\hline NUN
\end{tabular}

As for the 32 people of Chinese heritage, not all of them were born in China. Nine of them were the second generation of Chinese Australians and one was born in Malaysian. Among the rest 22 people, 18 of them came from Guangdong (Canton), and the other four came respectively from Shanghai, Shandong, Jiangsu (Kiangsu) and Beijing (Peking). These people are from all walks of life, like merchant, barrister, missionary, herbalist, riverboat captain, politician, photographer, teacher, artist, writer, aboriginal activist and so on, and many of them are community leaders. To some extent, these people can partly represent the picture of people of Chinese heritage in Australia, but compared with the people of English heritage, many people are missing in the historical soot. Referring to the British included, at least the following Chinese people should be recorded.

Charles Robert Darwin (1809-1882), a naturalist and the author of On the Origin of Species, landed at Sydney on 12 January 1836 and left Australia on 14 March 1836. He stayed in Australia for only three months and made some "superficial observations on the geology" and "collected some native fauna and flora". He was "rather disappointed in the state of society", and made the misjudgment that "agriculture can never succeed on an extended scale". [7] However, such a person like Darwin was recorded in the first volume of the $A D B$ in 1966, which shows he was highly regarded in the Australian national memory. An Australian city named after him is another testament. While an equally important Chinese figure, visiting Australia and staying much longer than Darwin, was completely ignored, and he investigated the Australian society and had much interaction with the people and local governments. This man is Liang Qichao, a chief leader of the ill-fated Hundred Days' Reform in China in 1898 and serializing an uncompleted monograph on Tung Hua News, a newspaper of Australia.

Another example is the comparison of Charles Dickens and Sun Johnson. Dickens, an English novelist, wrote, obsessed and published a lot about Australia in his novels like David Copperfield, Nicholas Nickleby and his journal Household Work, but with his most indelible baddies like Abel Magwith, John Edmunds and Wackford Squeers being transported down under. He, however, never stepped on the continent of Australia, although he "had contemplated a lecture tour of Australia in 1862 and intended to write a travel book" [8]. And he was recorded in volume 4 published in 1974, while Sun Johnson was forgotten though he lived, wrote and published in Australia and for Australians. Sun was the co-founder and editor of the first Chinese newspaper The Chinese Australian Herald [Guangyihuabao]) (1894-1923) published in Sydney and he wrote and published a book under the title Chinese English Self-educator in 1891 for the Chinese to learn English and for Australians to learn Chinese. He was also a coordinator between the white and the Chinese. Let alone Xue Fucheng, a Chinese Ambassador to United Kingdom in the end of 19th century, who wrote an essay "On Independence of Australia" and showed great expectations on the development of the Australian Chinese.

By comparison, we can find that people of Chinese heritage are underrepresented, so are people of Asian heritage, especially Vietnamese and Philippine. 


\section{Position of People of Chinese Heritage in the Australian National Memory}

"The $A D B$ is the great repository of the Australian identity," [9] although the $A D B$ tried to avoid the subject of national identity when the founders designed in 1960 that it was not possible to lay down rigid categories for inclusion and selection. [6] It claims that subjects in the $A D B$ have not been selected on any criteria to do with Australian character. Russel Ward, a section editor for Volumes 3-6, who held Australian character or identity aloft, did not impose radical national criteria for subject selection, nor did Gollan and Bede Nairn, who are called radical nationalism historians. [6] The $A D B$ is proud of itself on the inclusion of representative people, those of "ethnic and social minorities and of a wider range of occupations, or as innovators, notorieties or eccentrics" [6]. As Hancock judged, it was an improvement over the $D N B$ due to its inclusion of people "widely representative of endeavor and achievement on every front of our experience as an emergent nation” [6].

It should be admitted that the $A D B$ has made many efforts to include the ethnic and social minorities, but there is still room for improvement. As mentioned above, presently the people of Chinese heritage accounts for about four percent of the overall population and its percentage will continue to grow at a fast rate in the near future. Historically, the percentage of the people of Chinese people is not very low, at least higher than the percentage in the $A D B$, that is, 32 out of 12,955 only account for $0.25 \%$. In terms of individual, the gold digger from China is ignored, as is a big fault. Most of the Chinese people crowded into Australia for gold rush, but none of them is recorded in the $A D B$. According to the official records of Victoria, among less than 500,000 populations, there were about 42,000 Chinese people living in Victoria by 1861, and a quarter males were Chinese people in some goldfields. The actual number may be several times more than the official record, because smuggling was prevailing at that time in order to avoid the customs statistics and poll tax. There are some practical difficulties to trace these people, because most of them were farmers with little education and thus without written documents about themselves and isolated themselves from the white communities. Even so, some people were well educated and involved deeply into the European communities, like Chen Ah Kew, who developed "contacts and friendships at the highest levels in white Australia" [10], but he is not included in the $A D B$. Except business contacts, even the "pro-Chinese clique could rally against the Chinese when necessary" [11], so the Chinese people were hard to step into the Australian official documents. Racial barriers may be the main reason. Sun Johnson is another testament of racial barrier. What's more, to wrestle with racial barriers, some people with a high level of social engagement with Europeans adopted a strategy of assimilation and tried to erase the marks of Chinese heritage, like Jimmy Ah Foo from Cooktown or Billy Sing, half Chinese half English.

In fact, the Chinese people is the second largest group of Australian colony in the $19^{\text {th }}$ century, only next to BritishEnglish, Irish and Scottish in that order-and much more than Germans, North Americans and other Europeans.[12] What's more, the Chinese people is the unique group among
non-Europeans that exerted great impacts on the whole Australian society. But the Australian authority deliberately tried to downplay the existence and influence of the Chinese people in the historical narration of the nation, especially with the implementation of "White Policy" from the year 1901 on through legislation and institutionalization of Chinese exclusion.

There may be three reasons causing Chinese exclusion, namely cultural conflict, economic competition and environmental issue. In contrast with Europeans, the Chinese people are very different in many aspects, such as language, clothes, hairstyle, habits, customs, traditions, and modes of life, etc., which shows they are "foreigners". This "foreignness" made the White have "an objection to the different Chinese value system, a fear of being overrun by the vast population of China and the perceived failure of Chinese immigrants to assimilate with white society" [11]. Economically, the Europeans were hard to compete with the Chinese people, because the former desired "more pay for less work" while the latter were industrious, frugal, skilled and smart. Thus, they owned more and spent less so saved more than the Europeans, which challenged the Europeans' opportunism. Just in one year from 1 July, 1856 to 30 June, 1857, the Chinese people sent gold of 116,900 liang (appr. 31.25g) back to China, approximately equivalent to 500,000 pounds of that era. Their behaviors cannot be understood by the Europeans who upheld adventurism and Hedonism. They claimed that the Chinese people did not make any contribution to the development of the local economy, which is a main excuse of Chinese exclusion. Environmentally, some Europeans attributed environmental degradation to the Chinese people. They asserted that the Chinese gold diggers contaminated water sources and deteriorated soil structure in order to exclude them from the goldfields. Parallel to this appeal, the Australian authority made some policy to limit the Chinese people with the purpose of stabilizing social order of the colony. Facing public health problem, the Chinese people got rendered into source of disease transmission. Polygenists argued that certain races had aptitudes or immunities to particular diseases and that Chinese would infect Europeans with the "darker maladies" of cholera, typhoid, small-box and leprosy. Newspapers described Chinese mining camps as "putrid" "loathsome" "fetid" "vermin-ravaged" and warned of a "virulent Chinese plague" "decimating the white population". [13] Therefore, Chinese exclusion was supported by pathological evidence and the public enormously exaggerated that the body of Chinese was dirty and untouchable. The political elite and media elite sophisticatedly manipulated discourse of Chinese exclusion with the environmental issues to stress the identification of Europeans for one thing and to divert the public's attention of their governance failure to Chinese exclusion. Because of the above reasons and others, Chinese exclusion became a policy and the Chinese people were legally marginalized and concealed. All these reflected in the Australian national memory are low percentage of people of Chinese heritage recorded in the $A D B$ and it is also an embodiment of the will of the state.

Racial discrimination or Chinese exclusion has been proved to be a fault and "White Policy" has also been cancelled for 
more than 40 years. As a national memory, the $A D B$ should have the courage and ability to correct the fault. After all, just as Barry McGowan, an Australian historian and owner of a Medal (OAM) in the Order of Australia, pointed out in one of his speech, it is the Chinese people, especially those lived and worked in the rural areas, that are 'true' Australians. If these true Australians are ignored or neglected by the $A D B$ or the national memory, how can it provide "material for others to construct their own images of 'real' Australia or the 'typical Australian"” [6]? Or the real Australia is a white Australia?

\section{CONCLUSION}

The $A D B$ as a national memory is always under criticism. There have been criticisms of group omissions, like women, aborigines and the working class; there have been criticisms of groups over-represented, like the elite and people of some culture heritages. The $A D B$ is hard to be representative, after all, only 0.1 per cent people have chance of getting into it, but it should be improved, it should try to reflect a true Australia so as to survive the test of time. Especially for an emigrant nation, every ethnic group deserves equal treatment. In the present $A D B$, people of European descent are perhaps over represented while the people of Chinese heritage are under-represented; basically because Europeans were more visible and more literate and their histories better known to contemporary writers. By contrast, many accounts of the Chinese people and other non-Europeans groups rely on oral histories, unpublished family histories, and newspaper accounts of obituaries and other events. But these documents did exist, although they may not be put into the official cabinets. In fact, many Chinese men were prominent merchants, gardeners or farmers in regional Australia and very significant contributors to their local communities, and these people should be included in the $A D B$. In a word, the people of Chinese heritage, as a very important part of Australians, are both omitted and under-represented in the $A D B$, totally or individually. As a national memory, this kind of negligence will affect construction of Australian identity and the image of a "real” Australia.

\section{REFERENCES}

[1] Dictionary of Canadian Biography https://en.wikipedia.org/wiki/Dictionary_of_Canadian_Biography, $6 / 5 / 2018$.

[2] "What is the Oxford Dictionary of National Biography?". http://www.o xforddnb.com/oso/page/about;jsessionid=C56741D06C4B 055942D0523FC773D4B0 , 6/5/2018.

[3] http://adb.anu.edu.au/about-us/, 6/5/2018.

[4] “'They're going to buy the whole lot': Chinese property investment tipped to boom,"

http://www.news.com.au/finance/real-estate/buying/theyre-going-to-buy -the-whole-lot-chinese-property-investment-tipped-to-boom/news-story/ 8e75e5de3bc1bdafec38bff98dba5b40 , 22-7-2018.

[5] T. Su. "Chinese in the Australian Dictionary of Biography and in Australia”. Using Lives: Essays in Australian Biography and History. 2018.

[6] M. Nolan \& C. Fernon, Eds. The ADB's Story, Canberra: ANU E Press, 2013: p.xi, p.xi, p.21, p.22, p.22, p.23, p.22

[7] K.A. Townley. "Darwin, Charles Robert (1809-1882)." http://adb.anu.edu.au/biography/darwin-charles-robert-1957, 6/5/2018.

[8] C. Lansbury. "Dickens, Charles (1812-1870)." http://adb.anu.edu.au/biography/dickens-charles-3409 , 6/5/2018.

[9] G. Walsh, "From the First Fleet to 'Underbelly': Writing for the ADB". in Melan ie Nolan \& Christine Fernon, Eds. The ADB's Story, Canberra: ANU E Press, 2013, p. 260.

[10] B. McGowan. Tracking the Dragon. Canberra: CopyQik, 2015, pp. 108-109.

[11] K. Rains. "Webs of Association: Examining the Overseas Chinese Social Landscape of Early Cooktown,” Chinese Southern Diaspora Studies, Vol. 6, 2013, p.36, p.29.

[12] C. Fahey. "Peopling the Victorian Goldfields: From Boom to Bust, 1851-1901,” Australian Economic History Review, Vol. 50, No.2, 2010, p. 153.

[13] K. Cronin. Colonial Casualties: Chinese in Early Victoria, Melbourne: Melbourne University Press, 1982, p.69. 